\title{
FAKTOR-FAKTOR YANG MEMPENGARUHI IBU HAMIL TERHADAP PERILAKU VOLUNTARY COUNCELLING TEST (VCT)
}

\author{
Agustin Setianingsih ${ }^{1}$ Nur Khafidhoh ${ }^{2}$ \\ 1,2, Jurusan Kebidanan, Poltekkes Kemenkes Semarang, Indonesia
}

\begin{abstract}
HIV cases from 390,000 young children less than 15 years were newly infected with HIV, 90\% was a result of contracting through the mother to the baby. Distribution of HIV cases in 20112013 the highest in the district of North Semarang. The sub-district health centers Bandarharjo active by doing VCT, but pregnant women who do VCT only about $10 \%$ of from total pregnant women. The purpose of this study was to determine the factors that influence the behavior of pregnant women Voluntary Counseling And Test (VCT) in the sub-district health centers Bandarharjo North Semarang, Semarang. This research is an explanatory research with cross sectional method. Data collection techniques with interviews using a structured questionnaire. The population of this study were pregnant women in health centers Bandarharjo which is 45 pregnant woman. Sampling method with total sampling technique. The results showed $82.2 \%$ of pregnant women in the sub-district health centers Bandarhardjo not VCT. Variables that are not related is Pregnancy Awareness Level of HIV / AIDS and VCT $(p=0.272>0.05)$ and Maternal attitudes about HIV / AIDS and VCT $(p=1.000>0.05)$. Characteristics of pregnant women were age $80.0 \%$ of healthy reproductive age ( $20-35$ years ) , $48.9 \%$ secondary education , occupation housewife $46.7 \%, 62.2 \%$ husbands job working as an employee. Suggestion: For health professionals, especially midwives should do counseling asks respondents to disseminate to other friends about HIV IAIDS and VCT. For the Department of Health: Designing and implementing promotional execution prevention of transmission of HIV/ AIDS from mother to child transmission (PMTCT) and VCT counseling training.
\end{abstract}

Keywords : Behavior VCT; Pregnant women 


\section{PENDAHULUAN}

Acquired Immunodeficiency Syndrome atau Acquired Immune Deficiency Syndrome (AIDS) adalah sekumpulan gejala dan infeksi (atau: sindrom) yang timbul karena rusaknya sistem kekebalan tubuh manusia akibat infeksi virus HIV (Human Immunodeficiency Virus). HIV yaitu virus yang menurunkan kekebalan pada tubuh manusia. Orang yang terkena virus ini akan menjadi rentan terhadap sembarang infeksi ataupun mudah terkena tumor. Meskipun penanganan yang telah ada dapat memperlambat laju perkembangan virus, namun penyakit ini belum benar-benar bisa disembuhkan (Wikipedia, 2008).

Menurut catatan United Nations Joint Programme on HIV and AIDS (UNAIDS) jumlah orang dengan HIV/AIDS di dunia terus mengalami peningkatan. Pada tahun 2007 terdapat 33,2 juta orang dengan HIV/AIDS, 2,5 juta orang baru terinfeksi dan 2,1 juta meninggal disebabkan oleh HIV/AIDS termasuk 330.000 orang diantaranya adalah anak-anak (UNAIDS, 2008). Pada tahun 2009, jumlah HIV/AIDS menjadi 33,3 juta orang, penderita HIV baru 2,6 juta orang, 1,8 juta orang meninggal, 15,9 juta orang wanita dengan HIV/AIDS dan 2,5 juta adalah anak-anak. Pada tahun 2010, jumlah penderita HIV/AIDS di dunia meningkat hingga mencapai 34 juta orang, 17 juta orang wanita dengan HIV/AIDS, 3,4 juta anakanak termasuk diantaranya 390.000 orang adalah anak-anak berusia kurang dari 15 tahun yang baru terinfeksi HIV dan lebih dari $90 \%$ pada anak-anak tersebut, penularan melalui ibu ke bayi selama proses kehamilan, persalinan dan menyusui (UNAIDS,2011).

Diperkirakan tiap tahun ada sekitar 9.000 ibu hamil positif HIV yang melahirkan di Indonesia (Gemari, 2007). Jika tidak ada intervensi, setiap tahun bisa lahir 3.000 bayi positif HIV di Indonesia. Jumlah bayi lahir dari ibu HIV positif tiap tahun terus meningkat. Jumlah keseluruhan kasus bayi dilahirkan dari ibu HIV positif periode 19992005 adalah 143 kasus, sebanyak 81 bayi positif HIV. Pada tahun 2006 persentase kasus AIDS pada anak 5 tahun ke bawah mencapai $1 \%$. Diperkirakan sebanyak 4.360 anak tertular dari ibu HIV positif dan separuhnya telah meninggal. Pada tahun 2009 terdapat 3.045 kasus baru HIV pada anak dengan kumulatif kasus HIV pada anak 7.546 kasus, sedangkan pada tahun 2014 diperkirakan terdapat 5.775 kasus baru dengan 34.287 kasus kumulatif anak HIV di seluruh Indonesia (Yayasan Pelita IImu, 2011)

Berdasarkan data yang tercatat oleh Ditjen PPM \& PL Depkes, jumlah kasus AIDS di propinsi Jawa Tengah (Jateng) dari tahun 2008-2010 menduduki peringkat ke-7 di Indonesia. Sedangkan pada tahun 2011, Jateng menduduki peringkat ke-1 dengan jumlah kasus AIDS terbanyak yaitu 373 kasus.

Kota Semarang sebagai salah satu kota di Jawa Tengah menduduki peringkat 
paling atas sebagai kota dengan kasus HIV/AIDS terbanyak se-Jatengpada tahun 2008, yaitu 199 kasus HIV dan 15 kasus AIDS. Pada tahun 2009 jumlah kasus HIV/AIDS mengalami peningkatan menjadi 323 kasus HIV dan 19 kasus AIDS. Pada tahun 2010 jumlah kasus HIV mengalami penurunan menjadi 287 kasus HIV dan peningkatan kasus AIDS sebanyak 61 kasus. Hal ini disebabkan karena penjangkauan klien kurang optimal. Sehingga jumlah kasus kumulatif HIV/AIDS di kota Semarang pada tahun 2010 menjadi 650 kasus terdiri dari kasus AIDS sebanyak 146 kasus dan kasus HIV sebanyak 504 kasus (Dinkes Kota Semarang, 2010).

Data kasus HIV berdasarkan laporan klinik VCT pada tahun 2013 yang ditemukan di kota Semarang sebesar 430 kasus. Untuk kasus HIV kota Semarang 174 kasus dan 75 kasus sudah pada stadium AIDS (Profil kota Semarang, 2013).

Data dari Griya PMTCT PKBI Kota Semarang diperoleh bahwa program menjangkau ibu hamil resiko tinggi (suami potensial risiko tinggi), ibu hamil dengan keluhan IMS, dilakukan bekerjasama dengan Bidan Praktik Mandiri (BPM). Hasil kegiatan penjangkauan Griya PMTCT PKBI kota Semarang dengan BPS dalam waktu 6 bulan, sejak bulan Juni sampai Desember 2008 melalui kegiatan mobile VCT dapat menjangkau $315 \mathrm{lbu}$ hamil mengikuti pre-test dan 301 diantaranya bersedia mengikuti post-test, serta dari 301 ibu hamil yang mengikuti post-test ditemukan 2 ibu hamil Positiv HIV.

Hasil penelitian dari Ulfiana tahun 2013 menyebutkan bahwa masih sedikitnya ibu hamil yang melakukan VCT $46,7 \%$, sehingga perlu kegiatan PMTCT kepada ibu supaya tidak menularkan kepada bayinya (Ulfiana, 2014).

Data dari Dinas Kesehatan Kota (DKK) Semarang diperoleh informasi bahwa upaya pencegahan penularan HIV/AIDS pada ibu hamil dilakukan Dinas Kesehatan Kota Semarang bekerjasama dengan Komisi Penanggulangan Aids (KPA) kota Semarang, Perkumpulan Keluarga Berencana Indonesia (PKBI) kota Semarang, Lembaga Swadaya Masyarakat (LSM) peduli AIDS, Ikatan Bidan Indonesia (IBI), Ikatan Dokter Indonesia (IDI), serta dinas terkait lainnya.

Data ibu hamil di kota Semarang dapat dijangkau oleh Puskesmas sehingga pendekatan pelaksanaan Prevention of Mother to Child HIV/AIDS Transmission (PMTCT) ini, juga dikerjakan bersama dengan Puskesmas yang dianggap memiliki populasi beresiko antara lain Puskesmas Poncol, Puskesmas Bandarharjo, Puskesmas Karangdoro dan Puskesmas Halmahera. Selain itu, beberapa rumah sakit di kota Semarang yang juga menyediakan pelayanan PMTCT, antara lain Rumah Sakit Umum Pusat dr. Kariadi, RSU Panti Wilasa, RSU Tugu, RSUD Kota Semarang, BP4 serta pelayanan VCT di PKBI kota Semarang. 
Sebaran kasus HIV di kota Semarang dari tahun 2011-2013 tertinggi pada kecamatan Semarang Utara yaitu 46 kasus. Bandarharjo merupakan salah satu Puskesmas di kecamatan Semarang Utara yang cukup aktif melakukan VCT. Pada tahun 2013 ibu hamil yang melakukan VCT di Puskesmas Bandarharjo sebanyak 46 orang, namun jumlah ini hanya $10 \%$ dari jumlah ibu hamil yang periksa.

\section{METODOLOGI PENELITIAN}

Jenis penelitian ini adalah eksplanatory research, menggunakan metode pendekatan cross sectional atau studi potong lintang. Populasinya adalah seluruh ibu hamil yang berkunjung di Puskesmas Bandarharjo sebanyak 45 orang. Sampel diambil secara total sampling. Variabel yang diteliti adalah karakteristik meliputi umur, pendidikan, pekerjaan responden, pekerjaan suami responden, pengetahuan ibu hamil tentang HIV \& AIDS dan VCT, Sikap ibu hamil tentang HIV \& AIDS dan VCT dan perilaku (praktik) VCT pada Ibu Hamil. Instrumen penelitian dengan menggunakan kuesioner. Analisis data univariat dengan distribusii frekuensi dan bivariat dengan Chi Square

\section{HASIL PENELITIAN DAN BAHASAN}

Jumlah responden pada penelitian ini sebanyak 45 orang. Adapun karakteristik responden meliputi pendidikan, umur, pekerjaan responden, pekerjaan suami adalah sebagai berikut:

Tabel 1. Distribusi Frekuensi Karakteristik Responden

\begin{tabular}{|c|c|c|c|}
\hline No & KARAKTERISTIK & $\mathrm{N}$ & $\%$ \\
\hline \multirow[t]{4}{*}{1} & Pendidikan & & \\
\hline & a. Dasar & 18 & 40,0 \\
\hline & b. Menengah & 22 & 48,9 \\
\hline & c. Tinggi & 5 & 11,1 \\
\hline \multirow[t]{3}{*}{2} & Umur & & \\
\hline & a. Reproduksi sehat & 36 & 80,0 \\
\hline & $\begin{array}{l}\text { b. Reproduksi tidak } \\
\text { sehat }\end{array}$ & 9 & 20,0 \\
\hline \multirow[t]{7}{*}{3} & Pekerjaan Responden & & \\
\hline & a. IRT & 21 & 46.7 \\
\hline & b. Buruh Pabrik & 11 & 24.4 \\
\hline & c. Karyawan & 2 & 4.4 \\
\hline & d. Pedagang & 2 & 4.4 \\
\hline & e. Tak Tetap & 8 & 17.8 \\
\hline & f. POLRI & 1 & 2.2 \\
\hline \multirow[t]{9}{*}{4} & Pekerjaan suami & & \\
\hline & a. Buruh Pabrik & 5 & 11.1 \\
\hline & b. Guru & 1 & 2.2 \\
\hline & c. Karyawan & 28 & 62.2 \\
\hline & d. Pedagang & 2 & 4.4 \\
\hline & e. Pengemudi & 2 & 4.4 \\
\hline & f. Tidak Tetap & $\overline{5}$ & 11,1 \\
\hline & g. TNI/POLRI & 1 & 2.2 \\
\hline & h. Wiraswasta & 1 & 2.2 \\
\hline
\end{tabular}

Pada tabel 1 diperoleh bahwa sebagian besar responden memiliki pendidikan menengah sebanyak $48,9 \%$, bahkan dari data diketahui bahwa masih ada 1 responden yang hanya tamatan SD $(2,2 \%)$. Hal ini menunjukkan bahwa sebagian besar responden mempunyai daya intelegensia yang kurang. Hal ini akan mempengaruhi daya reaksi atau penyesuaian responden yang kurang cepat dan tepat, baik secara fisik maupun mental terhadap pengalaman-pengalaman dan situasi baru yang akan menjadi pengalaman dan pengetahuan yang dimiliki responden yang akan dipakai pada kondisi baru. Umur responden sebagian besar pada kelompok umur reproduksi 
sehat (20-35 tahun) sebanyak 80,0\%, sehingga responden masih produktif dalam proses reproduksi untuk hamil lagi. Responden paling muda berumur 18 tahun, paling tua berumur 39 tahun dan rata-rata responden berumur 28 tahun. Pekerjaan responden sebagian besar responden menjadi ibu rumah tangga sebanyak 46,7\%. Hal ini menunjukkan bahwa responden mempunyai kesibukan yang mengikat waktu sehingga tidak bisa dengan leluasa untuk mengikuti kegiatan yang dilaksanakan petugas kesehatan pada jam kerja. Sebagian besar suami responden bekerja sebagai karyawan sebanyak $62,2 \%$. Hal ini menunjukkan bahwa suami responden juga mempunyai pekerja dan kesibukan di luar rumah.

Tabel 2. Distribusi Frekuensi Responden Berdasar Pengetahuan tentang HIV/AIDS dan VCT

\begin{tabular}{llcc}
\hline No & \multicolumn{1}{c}{ KATEGORI } & $\mathrm{N}$ & $\%$ \\
\hline 1 & Pengetahuan & & \\
& tentang HIV/AIDS & & \\
& a. $\quad$ Baik & 27 & 60,0 \\
& b. Cukup & 13 & 28,9 \\
& c. Kurang & 5 & 11,1 \\
\hline 2 & Pengetahuan & & \\
& tentang VCT & & \\
& a. Baik & 21 & 46,7 \\
& b. Cukup & 9 & 20,0 \\
& c. Kurang & 15 & 33,3 \\
\hline 3 & Pengetahuan & & \\
& tentang HIV/AIDS & & \\
& dan VCT & 20 & 44,4 \\
& a. Baik & 17 & 37,8 \\
& b. Cukup & 8 & 17,8 \\
& c. Kurang & & \\
\hline
\end{tabular}

Hasil penelitian menunjukkan bahwa sebagian besar responden mempunyai sikap kurang tentang HIV/AIDS dan VCT sebanyak $51,1 \%$, sedangkan responden yang mempunyai sikap baik tentang HIV/AIDS dan VCT sebanyak $48,9 \%$.

Tabel 3. Distribusi Frekuensi Responden Berdasar Sikap lbu Hamil tentang HIV/AIDS dan VCT

\begin{tabular}{llcc}
\hline No & KATEGORI & $\mathrm{N}$ & $\%$ \\
\hline 1 & Baik & 22 & 48,9 \\
2 & Kurang & 23 & 51,1 \\
\hline Total & & 45 & 100 \\
\hline
\end{tabular}

Hasil penelitian menunjukkan bahwa sebagian besar responden tidak melakukan VCT sebanyak 82,2\%, sedangkan responden yang mempunyai melakukan VCT sebanyak $17,8 \%$.

Tabel 6. Distribusi Frekuensi Responden Berdasar Perilaku (Praktik) VCT pada ibu hamil

\begin{tabular}{llll}
\hline No & KATEGORI & $\mathrm{N}$ & $\%$ \\
\hline 1 & Melakukan & 8 & 17,8 \\
2 & Tidak Melakukan & 37 & 82,2 \\
\hline Total & & 45 & 100 \\
\hline
\end{tabular}

Pada kelompok responden yang melakukan VCT, proporsi responden yang mempunyai tingkat pengetahuan baik $(13,5 \%)$ lebih kecil dibandingkan responden yang mempunyai tingkat pengetahuan kurang (37,5\%). Pada kelompok responden yang tidak melakukan VCT, proporsi responden yang mempunyai tingkat pengetahuan baik $(86,5 \%)$ lebih besar dibandingkan responden yang mempunyai tingkat pengetahuan kurang (62,5\%).

Pada kelompok responden yang melakukan VCT cenderung mempunyai tingkat pengetahuan kurang dan pada kelompok responden yang tidak 
melakukan VCT cenderung mempunyai tingkat pengetahuan yang baik.

Hasil Uji statistik dengan taraf signifikansi $5 \%$ diperoleh nilai $p$ sebesar 0,272. Hal ini berarti tidak ada hubungan antara Tingkat Pengetahuan lbu Hamil tentang HIV/AIDS dan VCT dengan Perilaku (Praktik) Voluntary Counseling and Test (VCT).

Pada kelompok responden yang melakukan VCT, proporsi responden yang mempunyai sikap baik (18,2\%) lebih besar dibandingkan responden yang mempunyai sikap kurang (17,4\%). Pada kelompok responden yang tidak melakukan VCT, proporsi responden yang mempunyai sikap baik $(81,8 \%)$ lebih kecil dibandingkan responden yang mempunyai sikap kurang $(82,6 \%)$.

Pada kelompok responden yang melakukan VCT cenderung mempunyai sikap baik dan pada kelompok responden yang tidak melakukan VCT cenderung mempunyai sikap kurang.

Hasil Uji statistik dengan taraf signifikansi $5 \%$ diperoleh nilai $p$ sebesar 1,000. Hal ini berarti tidak ada hubungan antara sikap Ibu Hamil tentang HIV/AIDS dan VCT dengan Perilaku (praktik) Voluntary Counseling and Test (VCT

Hasil penelitian menunjukkan bahwa tidak ada hubungan antara variabel tingkat pengetahuan dan sikap lbu Hamil tentang HIV/AIDS dan VCT dengan Perilaku (Praktik) Voluntary Counseling and Test (VCT).
Hasil tabulasi silang menunjukkan bahwa sebagian besar ibu hamil di wilayah kerja Puskesmas Bandarhardjo tidak melakukan VCT $(82,2 \%)$. Hal ini sesuai dengan hasil penelitian Ulfiana tahun 2013 menyebutkan bahwa masih sedikitnya ibu hamil melakukan VCT 46,7\% (Ulfiana, 2014) yang berarti masih kurangnya kesadaran para ibu hamil dalam melakukan deteksi dini HIV/AIDS yang saat ini menjadi salah satu penyakit paling besar epidemicnya di Indonesia.

Menurut teori L. Green, seseorang berperilaku bisa dipengaruhi oleh factor predisposing, reinforcing, dan enabling. Faktor pengetahuan dan sikap sebagai salah satu factor Predisposing. Teori L. Green tidak sesuai dengan hasil penelitan yang telah dilakukan.

Hasil analisa Uji statistik dengan taraf signifikansi 5\% diperoleh nilai $p$ untuk tingkat pengetahuan dan sikap ibu hamil tentang HIV/AIDS dan VCT mempunyai nilai $p>$ dari 0,05 hal ini berarti bahwa tingkat pengetahuan dan Sikap lbu hamil tentang HIV/AIDS dan VCT tidak mempunyai hubungan dengan perilaku (praktik) ibu dalam melakukan VCT.

Penelitian ini tidak sesui dengan teori $L$. Green yang mengatakan bahwa sikap merupakan faktor predisposisi yang mempengaruhi perilaku seseorang. Menurut Rahmat, sikap mempunyai daya pendorong atau motivasi, relative lebih menetap, mengandung aspek evaluative, timbul dari pengalaman, tidak dibawa sejak lahir, tetapi merupakan hasil belajar. 
Secara teori, sikap dibentuk oleh kognitif yang dapat diukur dari pengetahuan. Namun, pendapat ini juga tidak sesuai dengan hasil uji bivariat antara pengetahuan lbu hamil tentang HIV/AIDS dan VCT dengan perilaku (praktik) VCT diketahui bahwa responden yang mempunyai pengetahuan tentang HIV/AIDS dan VCT baik tetapi sedikit yang melakukan perilaku (praktik) VCT.

Penelitian ini menunjukkan kesesuaian dengan pernyataan Fitriani (2011) yaitu suatu sikap belum otomatis terwujud dalam suatu tindakan (Overt Behavior), untuk mewujudkan sikap menjadi suatu perbuatan nyata diperlukan faktor pendukung atau suatu kondisi yang memungkinkan.

Tidak Adanya hubungan antara sikap lbu hamil tentang HIV/AIDS dan VCT dengan perilaku (praktik) Voluntary Counseling and Test (VCT) ditunjang oleh hasil penelitian yang menunjukkan bahwa sebagian besar responden (51,1\%) mempunyai sikap kurang. Hal ini di dukung oleh hasil jawaban responden yang menunjukkan bahwa masih banyaknya responden mempunyai sikap kurang baik tentang HIV/AIDS dan VCT disebabkan oleh karena sebagian besar responden tidak setuju jika operasi Caesar dapat mengurangi resiko penularan HIV dari ibu hamil HIV kepada bayi yang dilahirkannya (62.2\%), seorang bayi mempunyai resiko yang rendah untuk dapat tertular HIV dari ibunya jika tidak mendapatkan ASI (Air Susu Ibu) (53.3\%). Responden juga tidak setuju jika pengobatan Anti Retroviral Virus (ARV) pada ibu hamil dapat mencegah penularan HIV/AIDS dari ibu ke bayi (51.1\%).

Sikap ini dipengaruhi oleh tingkat pengetahuan responden tentang HIV/AIDS dan VCT. Hasil analisa jawaban pengetahuan ibu hamil tentang HIV/AIDS dan VCT menunjukkan bahwa sebagian besar responden beranggapan bahwa HIV/AIDS adalah penyakit keturunan (46,7\%). Sebagian besar responden tidak tahu cara pencegahan agar terhindar dari HIV/AIDS. Responden menganggap bahwa menggunakan alat makan khusus untuk diri sendiri (71.1\%) dan tidak bersalaman dengan penderita HIV (57.8\%) merupakan cara melakukan pencegahan agar terhindar dari penularan HIV \& AIDS. Responden banyak yang beranggapan bahwa penggunaan kamar mandi bersama di tempat umum bisa menularkan HIV (53.3\%). Masih banyak responden yang menganggap bahwa ciuman pipi dapat menularkan HIV/AIDS (46,7\%) termasuk ibu yang terkena HIV/AIDS dapat menularkan penyakitnya saat mencium pipi bayinya (46.7\%).

Responden lebih setuju bahwa alasan utama seseorang tidak mau melakukan VCT adalah karena tidak tahu tempat untuk tes HIV/AIDS (46.7\%). Hal ini sesuai dengan hasil analisa jawaban tingkat pengetahuan responden tentang HIV/AIDS dan VCT menunjukkan bahwa sebagian besar responden tidak mengetahui tempattempat pelayanan VCT. Dari hasil analisa 
jawaban, responden masih beranggapan bahwa pelayanan VCT tidak dilakukan di klinik KIA (Kesehatan Ibu \& Anak) (48.9\%), Puskesmas $(44,4 \%)$ dan klinik untuk terapi Tuberkulosa seperti di BP4 (44,4\%).

Responden lebih setuju jika seseorang tidak perlu tes HIV\&AIDS saat masih merasa sehat (53.3\%). Hal ini karena sebagian besar responden menganggap bahwa hasil tes HIV tidak akan dijamin kerahasiaannya oleh pihak yang melakukan tes itu (dokter, rumah sakit, atau laboratorium) (35.6\%). Sikap responden terbentuk disebabkan oleh kurangnya pengetahuan yang ditunjukkan dari hasil distribusi jawaban responden dimana sebagian besar responden tidak tahu bahwa salah satu pelayanan yang diberikan saat VCT adalah kegiatan konseling untuk mempromosikan perubahan perilaku yang bertanggung jawab (46.7\%). Jadi tidak perlu menunggu sakit terlebih dahulu untuk mengikuti kegiatan VCT.

Selain itu, dari hasil analisa distribusi jawaban responden tentang kegiatan VCT diketahui bahwa masih banyak responden yang tidak tahu tentang biaya untuk pelayanan di klinik VCT. Responden masih beranggapan bahwa jika melakukan VCT akan dikenai biaya tetapi murah karena mendapat subsidi dari pemerintah (84.4\%), ada yang beranggapan biaya VCT sangat mahal sehingga tidak terjangkau bagi masyarakat umum (64.4\%) dan masih banyak yang tidak tahu bahwa kegiatan VCT Gratis karena penanganan HIV \&
AIDS sudah menjadi program pemerintah (51.1\%).

Hasil penelitian ini mengungkapkan bahwa para responden yang mempunyai pengetahuan baik tidak otomatis diikuti dengan perilaku yang baik pula, bila tidak didukung oleh faktor yang lain.

Hasil analisa univariat dapat diketahui bahwa masih banyak responden yang hanya mempunyai tingkat pendidikan dasar $(40,0 \%)$, bahkan dari data diketahui bahwa masih ada 1 responden yang hanya tamatan SD $(2,2 \%)$, yang berarti bahwa masyarakat di wilayah puskesmas Bandarhardjo masih banyak yang mempunyai intelegensi yang kurang yang nantinya akan menghambat seseorang dalam menerima hal baru, salah satunya yaitu program VCT bagi ibu hamil.

Hasil analisa umur menunjukkan bahwa sebagian besar responden pada kelompok umur reproduksi sehat (20-35 tahun) sebanyak 80,0\%. Hal ini menunjukkan bahwa sebagian besar ibu di wilayah puskesmas Bandarhardjo masih mempunyai potensi besar untuk hamil lagi, hal ini berarti juga berpotensi besar untuk terjadi penularan HIV AIDS dari ibu kepada bayinya.

Penelitian ini menunjukkan bahwa sebagian besar responden adalah pekerja dengan waktu yang mengikat. Hal ini menunjukkan bahwa sebagian besar para ibu kesulitan untuk datang pada pelayanan VCT di Puskesmas karena pada waktu siang hari sebagian besar ibu hamil sedang bekerja di luar rumah. 


\section{KESIMPULAN}

1. Karakteristik ibu hamil meliputi umur responden sebagian besar pada kelompok umur reproduksi sehat (2035 tahun) sebanyak $80,0 \%$, pendidikan responden sebagian besar menengah sebanyak 48,9\%, pekerjaan respoden sebagian besar ibu rumah tangga sebanyak 46,7\%, pekerjaan suami responden sebagian besar bekerja sebagai karyawan sebanyak $62,2 \%$.

2. Pengetahuan responden tentang HIV/AIDS dan VCT sebagian besar baik sebanyak $44,4 \%$.

3. Sikap responden tentang HIV/AIDS dan VCT sebagian besar kurang sebanyak $51,1 \%$.

4. Perilaku (praktik) VCT pada ibu hamil sebagian besar tidak melakukan VCT $(82,2 \%)$.

5. Tidak ada hubungan tingkat pengetahuan Ibu hamil tentang HIV/AIDS dan VCT dengan perilaku (praktik) Voluntary Counseling and Test (VCT).

6. Tidak ada hubungan sikap Ibu hamil tentang HIV/AIDS dan VCT dengan perilaku (praktik)Voluntary Counseling and Test (VCT).

\section{DAFTAR PUSTAKA}

1. Aris, D. S. VCT Kurang Efektif, Ganti dengan PICT. Available from: http://www.satudunia.oneworld.net
2. Ayu. Layanan Baru untuk Penderita HIV/ AIDS di Indonesia. Indofamily NetHealth. Available from: http://www.indofamilyhealth.com.

3. BAPPENAS. Laporan Perkembangan Pencapaian Tujuan Pembangunan Milenium Indonesia. 2008. Available from: http//www.bappenas.go.id.

4. Beni, R. Pengetahuan dan Persepsi tentang AIDS dan PMS lainnya serta faktor-faktor yang mempengaruhinya. 2004. Available from:http:// www.bkkbn.go.id.

5. Direktorat Jenderal Pelayanan Medik Dirjen PPM dan PL. Jakarta. 2006

6. Departemen Kesehatan RI. Pedoman Nasional Pencegahan Penularan HIV dari lbu ke Bayi. Jakarta. 2006.

7. Diakses pada tanggal 11 Februari 2012.

8. Dinkes Kota Semarang. Profil Kesehatan Kota Semarang 2008. Semarang. 2008.

9. Dinkes Kota Semarang. Profil Kesehatan Kota Semarang 2009. Semarang.

10. Dinkes Kota Semarang. Profil Kesehatan Kota Semarang 2010 Semarang. 2010.

11. Dinkes Provinsi Jawa Tengah. Profil Kesehatan 2008. Semarang. 2008.

12. Dinkes Provinsi Jawa Tengah. Profil Kesehatan 2009. Semarang. 2009.

13. Ditjen PPMPL Depkes RI. Laporan Situasi Perkembangan HIV dan AIDS di Indonesia sampai dengan September 2011. Kemenkes RI. 2011.

14. Ditjen PPMPL Depkes RI. Laporan Situasi Perkembangan HIV dan AIDS di Indonesia sampai dengan Desember 2010. Kemenkes RI. 2010.Februari 2012. 
15. Griya PMTCT. PMTCT Services. 2008. Available from: http://www.blogger.com.

16. Kalla, J. National HIV/ AIDS Strategy 2003-2007. Office of The Coordinating Minister for People's Welfare/ National AIDS Commission. 2003.

17. Komisi Penanggulangan AIDS Jateng. Kondisi HIV/AIDS di Jawa Tengah 1993 s.d. 31 Desember 2010. Semarang. 2010.

18. Komisi Penanggulangan AIDS. Strategi nasional penanggulangan HIV/AIDS 2007-2010. Available from: http://www.spiritia.or.id.

19. Menteri Kesehatan RI. Pedoman Pelayanan Konseling dan Testing HIV/ AIDS Secara Sukarela ( Voluntary Counseling \& Test ). Depkes RI Direktorat Jenderal Pengendalian Penyakit dan Penyehatan Lingkungan. Jakarta. 2005.

20. Notoatmodjo, S. Pendidikan dan Perilaku Kesehatan. Rineka Cipta. Jakarta. 2003.

21. Sofro, Muhlis A. U. "Overview HIV/AIDS". Materi Seminar PMTCT. Fakultas Kedokteran Undip. Semarang. 2008.

22. Townsend, C. Cara pengobatan yang tepat dapat mencegah hampir semua risiko penularan HIV dari ibu ke bayi.Jurnal AIDS. 22(8):973-981, May 11, 2008.

23. UNAIDS. UNAIDS report on the global AIDS epidemic (online). 2011. Available from: http://www.unaids.org.

24. Wibowo, Bambang. "Pengelolaan Ibu Hamil dengan HIV". Materi Seminar PMTCT. Fakultas Kedokteran Undip. Semarang. 2008.

25. Yayasan Pelita IImu. Program Pencegahan Penularan HIV dari lbu ke Bayi (PMTCT) (online). 2011. Available from: http://www.ypi.or.id.
26. Yayasan Pelita IImu. Tes HIV dan VCT. Available from: http://www.ypi.or.id. 